\title{
Pulmonary arteriovenous malformation (PAVM) and pregnancy.
}

GuInar Murzabekova ${ }^{1}$, GulnarMustafinova ${ }^{1}$, ArlanRakhatayev ${ }^{1}$, Kamila Kalieva ${ }^{1}$, Kamila Dzheksenbieva ${ }^{1}$

${ }^{1}$ Corporate fund «University Medical Center» National Research Center for Maternal and Child health, department of obstetrics and gynecology, Astana, Kazakhstan.

\section{УДК 616.361:617.053}

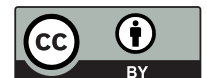

This work is licensed under a Creative Commons Attribution 4.0 International License

J CLIN MED KAZ 2017; 3(45 SUPPL 3):96-98 Автор для корреспонденции: Мурзабекова Гульнар Саркытказиевна, Корпоративный фонд «UniversityMedicalCenter» Национальный научный центр материнства и детства,отделение акушерства и гинекологии,ул.Туран 32, Астана, Казахстан. Телефон: +77019999934

E-mail: gulnara.murzabekova.47@mail.ru

\section{ABSTRACT}

Pulmonary arteriovenous malformation (PAVM) and pregnancy

Pulmonary arteriovenous malformation is very rare anomaly of the lung; the estimated incidence is thought to be around 2-3 per 100 thousand. Occurrence of this pathology in pregnant women has not been previously described in the literature.

\section{АРТЕРИОВЕНОЗДЫ ӨКПЕ АНЕВРИЗМАСЫ (АВӨА) ЖӘНЕ}

ЖҮКТІЛІК.

Мурзабекова Г.С. ${ }^{1}$, Мустафинова Г.T ${ }^{1}$ Рахатаев А.М. ${ }^{1}$, Калиева К. ${ }^{1}$, Жексембиева К.

${ }^{1}$ Ана мен бала ұлттық ғылыми орталығы «University Medical Center» корпоративтік қоры, акушерлік және гинекология бөлімі, Астана, Қазақстан.

\section{ТҰЖЫРЫМДАМА}

Артериовенозды өкпе аневризмасы сирек кездеседі, оның таралуы 100 мың адамға шаққанда 2-3 жағдайдан аспайды. Жүкті әйелдердің осы патологиясы әдебиетте бұрын сипатталған емес.

Артериовенозды өкпе аневризмасы (АВӨА) - өкпе қан-тамырларының бұзылысы эмбриональды кезеңнен бастама алғын, артерия мен вена және оң-сол жақ өкпеішілік қан тамырларында шоғыры арасында байланыс көрініс алады.

Артериовеноздық өкпе аневризмасының симптомдарының классикалық триады - диспепсия, цианоз, тырнақтардың деформациясы, саусақтардың фралангтарының қалыңдауы («Гиппократ саусақтары»), бірақ бұл белгілер науқастардың 10\% -ында ғана кездеседі. Көптеген жағдайларда кеудедегі ауырсыну, жөтел, фризикалық жүктеме кезіндегі шаршағыштық, қан жөтелу кездеседі.

Ұсынылған оқиға бірегей болып табылады, себебі тексеруден, диагноз дәлелденгеннен кейін, жүкті әйелге опретивті босану жасалып, өкпе аневризмінің бұзылуын хирургиялық емдеу жүргізілді.

\section{АРТЕРИОВЕНОЗНАЯ АНЕВРИЗМА ЛЕГКИХ (АВА ЛЕГКИХ) И БЕРЕМЕННОСТЬ.}

Мурзабекова Г.С. ${ }^{1}$, Мустафинова Г.Т. ${ }^{1}$ Рахатаев А.М. ${ }^{1}$, Калиева ${ }^{1}$, Жексембиева К.

'Корпоративный фонд «University Medical Center» Национальный научный центр материнства и детства, отделениеакушерстваигинекологии,Астана, Казахстан

\section{PEЗЮME}

Артериовенозная аневризма легких является редкой находкой; ее распространенность не превышает 2-3 случая на 100 тыс. населения. Данная патология у беременных раннее не описана в литературе.

Артериовенозная аневризма легких (АВА легких) - эмбриональное нарушение формирования сосудов легкого, при котором имеется сообщение между артериальными и венозными сосудами и право-левое внутрилегочное шунтирование крови. Классическую триаду симптомов артериовенозной аневризмы легких составляют одышка, цианоз, утолщение концевых фраланг пальцев рук с деформацией ногтей («пальцы Гиппократа»), однако данные признаки встречаются лишь у 10\% пациентов. Довольно часто возникают боли в грудной клетке, кашель, повышенная утомляемость при физической нагрузке, кровохарканье.

Представленный случай является уникальным, в связи с тем, что после проведения обследования, уточнения диагноза было последовательно проведено родоразрешение пациентки и оперативное лечение разрыва аневризмы легких, с благоприятным исходом для матери и плода. 


\section{Введение}

Артериовенозная аневризма легких (АВА легких) эмбриональное нарушение формирования сосудов легкого, при котором имеется сообщение между артериальными и венозными сосудами и право-левое внутрилегочное шунтирование крови. В пульмонологии артериовенозная аневризма легких является редкой находкой; ее распространенность не превышает 2-3 случая на 100 тыс. населения.

Несмотря на преимущественно врожденный характер ABA легких, лишь в $10 \%$ наблюдений клинические проявления патологии возникают в детском возрасте. У остальных больных манифестация заболевания приходится на второе, третье и четвертое десятилетие жизни. Артериовенозная аневризма легких диагностируется у мужчин и женщин с приблизительно одинаковой частотой.

В литературе ABA легких также описана под названиями артериовенозная фистула (свищ), кавернозная ангиома, гемангиома, телеангиоэктазия, кавернозный синус, артериовенозная мальформация легких.

\section{Описание случая}

Артериовенозные аневризмы легких могут носить единичный (60-70\%) или множественный характер (30$40 \%$ ). Три четверти больных имеют одностороннее поражение легких, остальные - двустороннее. В большинстве случаев (65-70\%) местом локализации артериовенозных аневризм служат нижние доли легких, чаще справа.Соустья между артериями и венами могут формироваться на уровне сегментарных, субсегментарных легочных сосудов, артериол и прекапилляров. Если между собой сообщаются сосуды среднего и крупного калибра, то патология классифицируется как артериовенозный свищ; аномалии более мелких сосудов, образующих мешотчатые расширения, принято относить к артериовенозным аневризмам.

По форме артериовенозные аневризмы легких могут быть округлыми, овальными, грушевидными или гроздьевидными, состоящими из нескольких полостей различного размера (от 1 до 5-10 см).Различают простые ABА легких (при сообщении одной артерии с одной веной) и комплексные артериовенозные мальформации (при сообщении двух и более питающих артерий с несколькими дренирующими венами).

В $80 \%$ случаев артериовенозные аневризмы легких являются врожденными, первичными сосудистыми мальформациями. Причины их формирования, как и других пороков развития легких, связаны с различными пренатальными вредностями: радиационным, электромагнитным, химическим, биологическим воздействием на плод, токсикозами и заболеваниями беременной и пр. Первичные артериовенозные аневризмы легких могут являться изолированными аномалиями или служить частью врожденных синдромов, в частности, наследственной геморрагической телеангиэктазии, или болезни Рандю-Ослера-Вебера. Структуру данного наследственного заболевания составляет наличие множественных телеангиэктазий и ангиом на коже и слизистых, артериовенозных соустий в легких, склонность к кровотечениям различных локализаций. Возможно сочетание АВА легких с врожденными пороками сердца.

Гораздо реже встречаются вторичные артериовенозные аневризмы легких, формирующиеся после рождения вследствие других заболеваний: цирроза печени, инфекционных поражений легких (актиномикоза), митрального стеноза, метастатических карцином и др.При макроскопическом изучении артериовенозная аневризма определяется в виде тонкостенного кистозного образования в легком, иногда с дольчатым строением. На разрезе в полости аневризмы обычно обнаруживаются кровяные сгустки, а в стенках - фибролипидные и известковые отложения. Выраженность симптоматики при артериовенозных мальформациях легких может варьироваться в широких пределах: от полного отсутствия проявлений до тяжелых форм дыхательной и сердечной недостаточности. Это зависит, главным образом, от количества и размеров артериовенозных аневризм легких. Так, единичные АВА диаметром менее 2 см обычно протекают бессимптомно; чаще клиника развивается при множественных сосудистых аномалиях.

Классическую триаду симптомов артериовенозной аневризмы легких составляют одышка, цианоз, утолщение концевых фаланг пальцев рукс деформацией ногтей («пальцы Гиппократа»), однако данные признаки встречаются лишь у $10 \%$ пациентов. Довольно часто возникают боли в грудной клетке, кашель, повышенная утомляемость при физической нагрузке, кровохарканье. Следствием гипоксемии служат головокружения, синкопальные состояния.При сочетании артериовенозной аневризмы легких с болезнью РандюОслера-Вебера типичны носовые и желудочно-кишечные кровотечения, геморрагии из кожных телеангиэктазий, приводящие к постгеморрагической анемии.Осложнениями артериовенозной аневризмылегких могут стать септические, геморрагические, тромбоэмболические состояния. Наиболее часто встречаются цереброваскулярные поражения, включающие мигренозные головные боли, транзиторные ишемические атаки, ишемический инсульт. При наличии воспаления в АВА могут возникать абсцессы мозга и инфекционный эндокардит. В случае разрыва аневризматического мешка в просвет бронха развивается профузное легочное кровотечение, в полость плевры гемоторакс.

О затруднениях в дифференциальной диагностике этих заболеваний в условиях повседневной практики сообщают и другие авторы. Так, М. И. Перельмап и соавт. (1965) указывают, что 7 из 17 больных, страдавших артерио-венозной ангиомой, от 3 до 30 лет наблюдались в противотуберкулезных учреждениях. Такие же данные приводят Л. С. Розенштраух и А. И. Рождественская (1968).Аускультативные феномены, характерные для артериовенозной аневризмы легких, включают систодиастолический шум, усиливающийся на вдохе, «кошачье мурлыканье», шум «волчка».Объективно определяется цианоз кожи и видимых слизистых оболочек, деформация пальцев рук в виде «барабанных палочек» и ногтей по типу «часовых стекол». Данные лабораторных анализов (гемограммы, исследования газового состава крови) обнаруживают полицитемию, снижение насыщения крови кислородом.На рентгенограммах легких артериовенозные аневризмы выявляются как одиночные или множественные округлые, четко очерченные затемнения, чаще в проекции нижней доли. Сосудистая природапатологии подтверждается при проведении функциональных проб Вальсальвы и Мюллера: в этом случае колебание внутригрудного давления влечет за собой увеличение или уменьшение притока крови к аневризме и изменение ее размеров. Более точную информацию о характере образования удается получить с помощью ангиопульмонографии и МСКТ с 
контрастированием легочных сосудов, перфузионной сцинтиграфии легких. Рентгеноконтрастные исследования позволяют визуализировать питающий и дренирующий сосуды, патологическое шунтирование крови из артерии в отводящую вену. Дифференциальный диагноз проводится c лобарной эмфиземой, туберкуломой, солитарными воздушными кистами легких.

Тень ее АВА изменяется при дыхании, при пробах Вальсальвы и Мюллера; она пульсирует и связана с корнем легкого наподобие «кометы». Этот признак лучше выявляется на томограммах, особенно в косых проекциях.

Лечебная тактика в отношении артериовенозных аневризм легких может быть различной. В случае множественных мелких сосудистых мальформаций приходится ограничиваться проведением консервативной симптоматической терапии. При небольших одиночных артериовенозных аневризмах методом выбора служит интервенционная хирургия - чрескатетерная эндоваскулярная окклюзия артериовенозного соустья. В остальных случаях, в зависимости от уровня поражения и калибра сообщающихся сосудов показаны резекционные вмешательства, объем которых может варьировать от атипичной и сегментарной резекции легкого долобэктомиии или пневмонэктомии.

В нашем наблюдении представлен случай развития беременности у пациентки с артериовенозной аневризмой легких, 23x лет, которая поступила в АО «национальный научный центр материнства и детства, с диагнозом: «Беременность 40 недель. Нижнедолевая левосторонняя пневмония? Туберкулез легких? Хронический панкреатит?»При поступлении жалобы на боли в левом подреберье до задней подмышечной области, чувство нехватки воздуха.Из анамнеза: в 2008 году при прохождении медицинского осмотра - подозрение на туберкулез легких, дообследована в условиях АО национального научного медицинского центра - выявлена, со слов, сосудистая патология.

Данная беременность - 1, роды - первые. За период гестационного процесса течение беременности - без осложнений.При поступлении состояние средней степени тяжести, тяжесть состояния обусловлена патологией легких. Кожные покровы и слизистые бледно-розовой окраски. Дыхание самостоятельное, адекватное, ЧДД-17 в мин, сатурация 98\%. В легких дыхание везикулярное, проводится по всем полям, хрипов нет, ослабление дыхания в нижних отделах легких. Локально пальпация в 3-5 межреберье слева болезненная.

В отделении проведено полное клинико-лабораторное обследование. Пациентка была осмотрена специалистами: торакальными хирургами, хирургом-фтизиатром.В общем анализе крови обнаружена анемия 1 степени, гемоглобин составил 89г/л, умеренный лейкоцитоз без сдвига влево (лейкоциты-14,4х10*9/л, моноц 7, лимф 12,0, СЯН-81, СОЭ-50); изменения коагуляционного и тромбоцитарного гемостаза не обнаружены, остальные лабораторные данные в пределах допустимых величин. ЭхоКГ от 22.09.2015г: Уплотнение корня аорты, передней створки митрального клапана. Незначительная дилатация полости ЛЖ, ствола ЛА, полости правого предсердия. ТР $(1,0+)$ ПР (1+) РСДЛА= 43 мм.рт.ст. Умеренная ЛГ. Незначительная ГЛЖ. Мизерный выпот в перикарде. МАРС: ПМК 1 степени. Минимальная МР ДХЛЖ. Позади ЛЖ, за перикардом, наличие огромного солидного образованияУЗИ плевральной полости от 22.09.2015г: Незначительный выпот и образование в левой плевральной полости.Компьютерная томография органов грудной клетки от 22.09.2015г: КТ признаки сегментарной пневмонии в верхней доле левого легкого, гемогидроторакса слева.

Заключение торакального хирурга: Массивный гемоторакс слева. Постгеморрагическая анемия. Ателектаз правой доли левого легкого. Продолжающее внутриплевральное кровотечение слева в следствии разрыва аневризмы. Рекомендовано: Учитывая левосторонний субтотальный гемоторакс, продолжающееся внутриплевральное кровотечение вследствие разрыва аневризмы, решено родоразрешить путем операции кесарево сечения в экстренном порядке, с последующей торакотомией и гемостазом.

Заключительный диагноз: Беременность 40 недель. Левосторонний субтотальный гемоторакс с продолжающимся внутриплевральным кровотечением вследствие разрыва аневризмы. Ателектаз правой доли левого легкого. Постгеморрагическая анемия.В стационаре при сроке беременности 40 недель произошли срочные оперативные роды, путем кесарево сечение. Извлечен живой, доношенный ребенок женского пола, массой - 3350,0 гр., рост - 53 см, 6-8 баллов по Апгар. Ранний неонатальный период протекал без осложнений.

\section{Обсуждение}

Сразу после окончания оперативного родоразрешения пациентке проведена экстренная торакотомия, удаление гемоторакса, ушивание аневризмы легкого, устранение ателектаза правой доли левого легкого. Общая кровопотеря составила 2700 мл. В раннем послеродовом периоде была проведена трансфузия лейкофильтрованной эритроцитарной взвеси и свежезамороженной плазмы.

Послеоперационный послеродовый период протекал без осложнений. В стационаре проводилась комплексная терапия, направленная на профилактику кровотечения, лечение анемии, проводилась антибактериальная и инфузионная терапия.

Пациентка выписана домой в удовлетворительном состоянии совместно с ребенком.

\section{Выводы}

В данном случае у беременной пациентки вовремя было диагностировано осложнение артериовенозной аневризмы легких - разрыв аневризмы легких, были проведены своевременно лечебные мероприятия.

\section{Литература:}

1. Kosarev V.V., Babanov S.A. Spravochnikpulmonologa, 2011; 16(9): 445-446.

2. Korovkin V.S. Aktualnyieproblemyipulmonologii, Med. Panorama. 2000; 3(6):2-5. 